\title{
The development of science process skills in visually impaired
} students: analysis of the activities

\author{
Aydın Kizılaslan \\ Department of Special Education, Agri Ibrahim Cecen University, Turkey
}

\begin{tabular}{l}
\hline \hline Article Info \\
\hline Article history: \\
Received Dec 27, 2018 \\
Revised Jan 20, 2019 \\
Accepted Feb 26, 2019 \\
\hline
\end{tabular}

Keywords:

Science activity

Science process skills

Teaching science

Visual impairment students

\begin{abstract}
Students with visual impairments face tremendous challenges in daily life while learning life skills as they do not have the benefit of visual cues. The skills that visually impaired students are expected to learn include not only everyday life skills, but also scientific process skills too. In this study, case study was used to develop an instructional design to teaching science concepts to visually impaired students. The aim of this study is to analyze the efficacy of science activities of this developed instructional design. The study consists of three basic stages. In the first stage, visually impaired students' learning needs are identified. In the second stage teaching materials and activities are designed and developed. In the last stage, these activities were analyzed in terms of scientific process skills through observation forms. As a result, most of the developed activities are suited for development of the scientific process skills.
\end{abstract}

Copyright (C) 2019 Institute of Advanced Engineering and Science. All rights reserved.

\section{Corresponding Author:}

Aydin Kizılaslan,

Department of Special Education, Agri Ibrahim Cecen University, Agri, 04800, Turkey

Email: ydnkizilaslan@gmail.com

\section{INTRODUCTION}

There is no doubt that the science has an influence striking on changes in the modern society and there is no challenge or threat affecting our society that does not have an appropriate solution through scientific research. Science helps us to describe, explain, define, investigate, and ultimately try to brighten and clarify the real world phenomena and how it works. Besides that, science integrated with technology is increasingly important to economic and social well-being and improving quality of life. National Science Education Standards [NSES] has a vision of scientifically literate individuals as those who needs to know, understand, or be able to predict natural phenomena [1].

Scientific literacy skill is conceptualized various ways but generally known as the knowledge, understanding and shaping of our daily lives by decision making, interacting with environment, asking questions that derived from curiosity about everyday experiences and finding or determining answers to questions. Such essential skills for students to develop their abilities in science are also known as numeracy skills. Students should able to learn how to build or develop self-confidence and improve their self-esteem and to learn the ability how to apply these skills to different learning areas such as at school and in their lives beyond the classroom. On the other hand, scientific literacy does not only mean to be a part of the scientific process, it is also expressed by National Research Council, [NRC] as "scientific literacy entails being able to read with understanding articles about science in the popular press and to engage in social conversation about the validity of the conclusions" [2]. That is, briefly scientifically literate students should be able to interpret the quality of scientific knowledge on the basis of its source to define and clarify the issue faced in daily life, use the scientific methods and find reasonable answer of issues underlying national and local decisions. 
The principle to ensure that all students regardless of race, gender, or disability are provided with opportunities to learn and understand the essential science content is the main basis of NSES defined as "science for all students" [2]. This dignified, meaningful and rigorous objective emphasized by NSES as "the commitment to Science for All implies inclusion not only of those who traditionally have received encouragement and opportunity to pursue science, but of women and girls, all racial and ethnic groups, the physically and educationally challenged, and those with limited English proficiency" [2]. So this fact has been emphasized by special educator as science education as one of the most useful and most valuable content area for many students with disabilities [3]. The affiliate of NSES, The Foundation for Science and Disability, founded in 1978, aspire to remove the barriers in order to enable actively participation of students with disabilities to all activities of the scientific community, to have opportunities to choose careers in science, to provide the integration of them into the science, technological, engineering, and mathematical (STEM) [4].

Besides that the law that intend to provide all children with a fair, equal, and significant opportunity to obtain a high-quality education and to concern the way how to overcome the widening achievement gap between students from disadvantaged groups -defined as disabled, race, ethnic group, poverty or sex- and their peers known as No Child Left Behind Act (NCLB) emphasizes four essential principals; ensuring disadvantaged students achieve academic proficiency, offering more flexibility in using education funds, increasing parents awareness, and emphasizes educational programs based on scientific inquiry [5]. Reading/language arts, math and science are important subject under NCLB for developing yearly student academic assessments.

The development of many skills such as problem-solving, inquiry, thinking and learning are concerned with the development of through "hands on" activities with "minds on" grasp. One of the most pervasive and crucial goals of science education is to focus on the teaching and acquisition of basic and integrated science process skills [6]. Acquiring many of 21st-century skills such as critical and creative thinking, problem solving, decision-making, scientific literacy and information literacy can be fostered through scientific activities and scientific knowledge that is linked with reasoning and thinking skills [7].

Science content is less accessible to the students with blindness or low vision due to the overreliance on visual instruction and abstract nature of concepts. Therefore, students show significantly lower achievement in science compare to their sighted peers [8], [9]. The basic foundation of the teaching science, highly recommended being as manipulative and interactive with materials in the learning environment. Namely, exposing students to variety of experiences in science activities that can reasonably be explored is critical in stimulating the intellectual growth of students with visual disabilities [10]. By this way, student's awareness is expected to arise in science lessons [11], [12]. Students typically need variety of opportunities to explore and examine real materials or models by provide a wide range of hands-on learning experiences [13]. Besides that, some accommodations should be done in science classroom and laboratory in order to safely and fully access the science curriculum and to overcome the lacking in willingness to participate the science lessons [14]. On the other hand, carefully revising and rearranging the science education curricula, and considering how to make it accessible with characteristics of students with disabilities is the crucial point that special educators keep in mind [15], [16]. The students' unique needs mostly ignored when determining how to make materials accessible as well (i.e. measuring devices, reading charts and written materials, and laboratory equipment).

Although there are so many studies on students with visual impairment in the literature, only a few of them are about science education [17]. The content of these studies are usually related to the providing students with the ability to adapt to science courses, accommodations in the classroom and instructional material that students often need in science, technology, engineering and mathematics (STEM). In this study, we designed science activities and evaluated the efficacy of these activities on science process skills development.

\section{RESEARCH METHOD}

The study was conducted through design based research. As seen at Figure 1, DBR is used as a response to reduce widening achievement the gap between theory and practices in education issues, and to make educational research meaningful for the preferable educational systems. This fact is specified "design based research is a methodology designed by and for educators that seeks to increase the impact, transfer, and translation of education research into improved practice [18]. In addition, it stresses the need for theory building and the development of design principles that guide, inform, and improve both practice and research in educational contexts". 


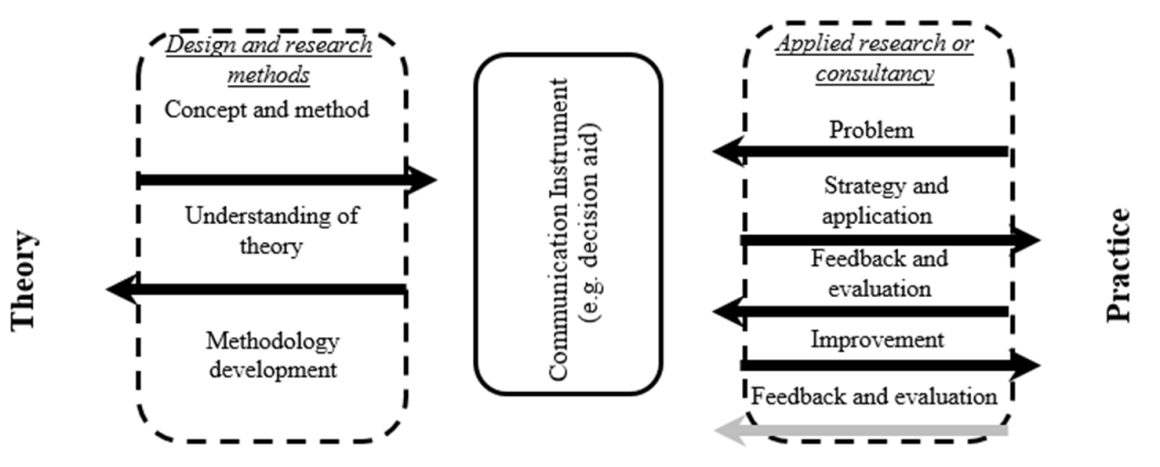

Figure 1. Theoretical structure of design-based research.

The study was carried out through these three steps. The case study was used at the first and third steps of the study. At the first the visually impaired students' unique needs related to science lessons were determined. Besides that, students' essential needs related physical environment, teaching, learning and assessment-evaluation process were analyzed to attain reasonable inference for accomplishment of design model. At this step, the embedded single-case study was used at first step of study to get enrichment data about students' needs mentioned above. Embedded case study contains more than one sub-unit of analysis, so that more complex (or embedded) design is to be developed to analyze all sub units and gather around a single purpose [19]. The subunits that are defined as students' needs (physical environment, teaching, learning and assessment-evaluation process) were analyzed for the significant contribution of the extensive analysis of the single case. Science Observation Form (SOF) was used as a data collection tool to determine the students' learning needs about science lesson. In the part designated as 'How was the lesson?' in the observation form is reversed to determination about how the course is carried out, the second part of the form is designated to analysis of the student' needs about lesson, and lastly the third part 'Observer Notes' is designated to the observer's evaluations.

At second step of the study, and activities and activity materials related to 'structure of matter' unit and also instructional materials (instructor's guide and student handouts) were designed in the direction of students' need that is determined at the first step. As a result, 9 activities were designed. An activity could include more than one learning outcomes. For example, for the learning outcomes defines as: 'recognize that the motion energies of each molecule may be different and will change with collisions' and 'interpret the temperature as a sign of the average kinetic energy of the molecules' and aim to teach the concept of temperature an activity of the were designed. Besides activity materials, the teaching methods techniques and the science process skills related to each activity were determined. For example, activity 1 were planned to develop the science process skill; observation, measurement-classification and analytical thinking.

Activity Based Instruction is as the teaching method used during the implementation of the activities at the classroom. ABI facilitate self-directed learning and problem-solving skills. Because it enables students to be willing with enthusiasm internalize and implement concepts relevant to their needs, make judgments on a subject based on activities and observations, and emphasizes the interactive interaction of the teacher with the them [20]-[22].

Instruction material designed for teacher contains the information about the purpose of activity, the common misconception student may have related about learning outcomes, the duration of each lesson, the question that teacher should ask during activities and the information about how the lesson should be processed. On the other hand, the handouts designed for student, basically contains the directives on what will be done during lesson and information about the activity materials. Activity materials that have been developed in accordance with the material development principles which are designated by special education and science education scholars are diversified to allow the use of hearing and tactile senses. By the way, the activity materials have been chosen from daily life to ensure the knowledge transfer between the activities to the daily life. Besides this, for the students with low vision Century Gothic font and font size 18 and for the blind students Braille documents were designed and used. Century Gothic and font size 18 was identified as the best readable font by visually impaired students [23]. At the implementation phase, instructional model was applied to students with visually impaired students. The implementation of the study has lasted nearly three weeks.

At the third step, Science Activity Observation Form (SAOF) was used as a data collection tool to analyze the effectiveness, applicability and usefulness of the instructional model. This stage was carried out

Int. J. Eval. \& Res. Educ. Vol. 8, No. 1, March 2019: 90 - 96 
as an evaluated single-case design. Evaluative case studies involve in-depth description, explanation, judgement and analysis of causal links of a program, project, or other development activity.

\subsection{Sample of study}

The study has carried out at segregated school for visual impaired students. Sample of the study consist of four students. Purposive sampling enables us to studying a specific characteristic, feature or function and provide assist to be clear on informant qualifications about sampling. Sample of study presented in Table 1.

Table 1. Sample of the study

\begin{tabular}{cccc}
\hline Student Code & Visual Acuity & Gender & Level of Inadequacy \\
\hline $\mathrm{S}_{1}$ & Blind & Male & Totally \\
$\mathrm{S}_{2}$ & Blind & Male & Both eyes \\
$\mathrm{S}_{3}$ & Low vision & Male & Both eyes \\
$\mathrm{S}_{4}$ & Blind & Female & Both eyes \\
\hline
\end{tabular}

\section{RESULTS AND ANALYSIS}

The results obtained from the analysis of the observations are presented at this section. At need analysis stage, the students' needs for learning science lessons were determined by unstructured observations. At the implementation phase, semi-structured observations were made to determine the effectiveness, applicability and usefulness of the instructional design model. The results are presented as two subtitles as a needs analysis stage results and implementation stage results. The data obtained from the observations were subjected to descriptive analysis.

\subsection{Needs results}

In this section, the descriptive analysis of data that is gathered from SOF observation from will be given here. In order to ensure validity and reliability, the notes kept on the first observation form were compared with recorded videos after every lesson. Additionally a copy of the observation form was given two experts to watch the videos and record their observations. It was requested from experts to watch the activity videos and examine whether the activities were efficient on acquiring of planned skills. A common consensus is reached after examining the different analyzes. Table 2 shows observational data on needs analysis before designing of the first activity of the instructional design.

Table 2. Observation of the lesson

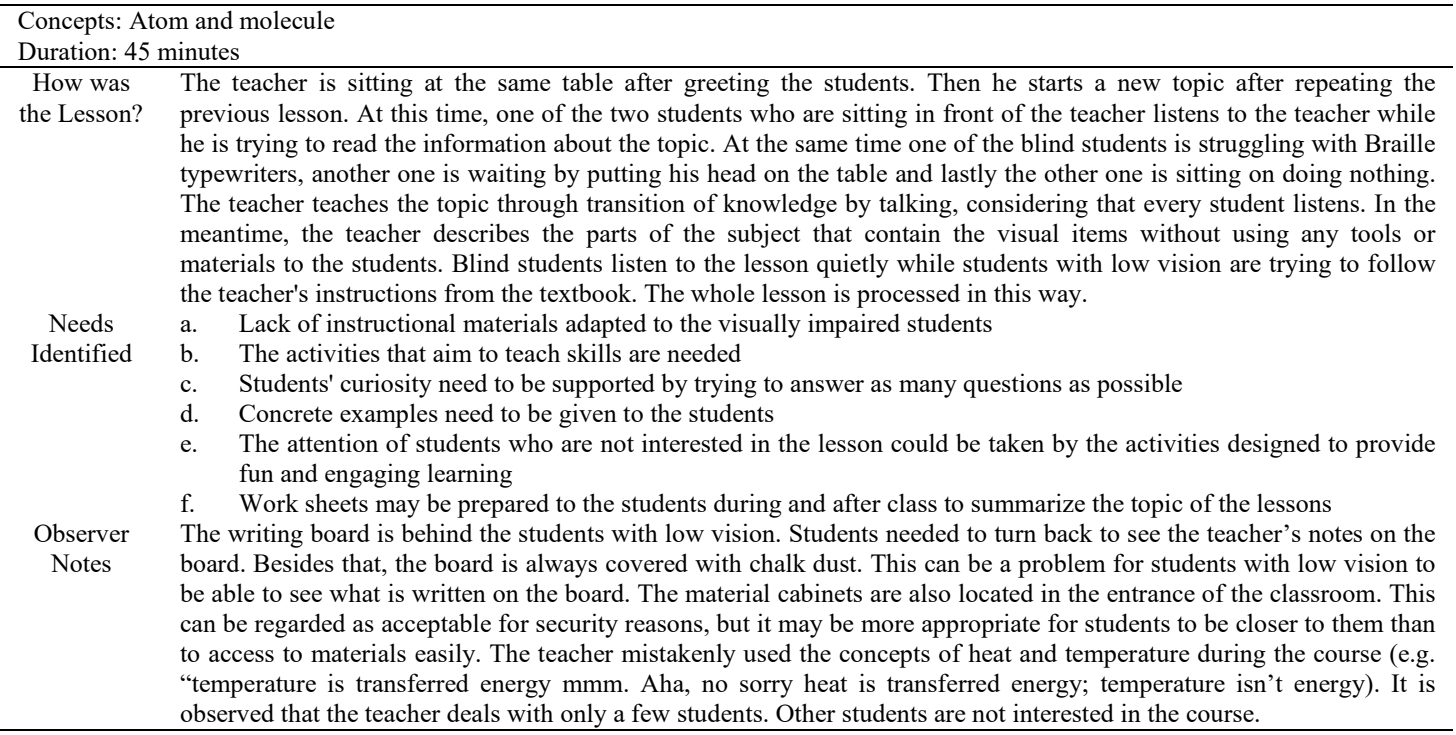

It was observed that the teacher did not use essential teaching strategies effectively. Instruction was teacher-centered so the students were extremely unattended against what teacher teaches. Unfortunately 
many students have misconceptions about the first and fifth learning outcomes that are concentrated on teaching the concepts of heat and temperature. A simple and concise activity may be designed by considering the students' unique needs. By this activity, which merely emphasizes tactile perception, students are expected to understand that heat is an energy type transmitted from cold to hot by the help of an ice sheet and hot water.

In Turkey, there are great difficulties in educating disabled people about science education. Since science teachers have no formal education on how to teach science to disabled students in their undergraduate education, unexperienced teachers are working in all special education schools. Therefore, science teachers are having problem in adapting instructional activities to the needs of students and having trouble motivating them. Through simple and effective activities, their (students and teacher) motivations can be increased. This can only be achieved with fun and effective activities. To carry out these activities effectively it was deemed to prepare a teacher's guidebook containing effective teaching strategies and activities.

\subsection{Implementation}

In this section, the findings obtained from the descriptive analysis of data that is gathered from SAOF observation from will be shown. In addition, a video recording and SAOF have given a specialist researcher to make a comparison between results. The very few differences arisen have been resolved after the concluding consensus on the findings of the specialist researcher. Table 3 describes analysis of activities according to science process skills.

Table 3. Analysis of activities according to science process skills

\begin{tabular}{|c|c|c|c|c|c|c|c|c|c|c|c|c|}
\hline & Activit & & Obs & Mc & $\mathrm{Dr}$ & Нур & $\mathrm{U}$ and $\mathrm{m}$ & Tv & Exp & $\mathrm{Ct}$ & $\mathrm{Dm}$ & $\mathrm{C}$ and $\mathrm{t}$ \\
\hline \multirow{3}{*}{1} & Take & Yes & & $\checkmark$ & & & & & & $\checkmark$ & & \\
\hline & place & No & & & & & & & & & & \\
\hline & $\begin{array}{l}\text { Planned } \\
\text { Situation }\end{array}$ & & + & + & & & & & & + & & \\
\hline \multirow{3}{*}{2} & Take & Yes & $\checkmark$ & $\checkmark$ & & & & & & $\checkmark$ & & \\
\hline & place & No & & & & & & & & & & \\
\hline & $\begin{array}{l}\text { Planned } \\
\text { Situation }\end{array}$ & & + & + & & & & & & + & & \\
\hline \multirow{2}{*}{3} & $\begin{array}{l}\text { Take } \\
\text { place }\end{array}$ & $\begin{array}{l}\text { Yes } \\
\text { No }\end{array}$ & $\checkmark$ & $\checkmark$ & $\checkmark$ & & & & $\checkmark$ & & & \\
\hline & $\begin{array}{l}\text { Planned } \\
\text { Situation }\end{array}$ & & + & + & + & & & & + & & & \\
\hline \multirow{2}{*}{4} & $\begin{array}{l}\text { Take } \\
\text { place }\end{array}$ & $\begin{array}{l}\text { Yes } \\
\text { No }\end{array}$ & $\checkmark$ & & & & & $\checkmark$ & & & & $\checkmark$ \\
\hline & $\begin{array}{l}\text { Planned } \\
\text { Situation }\end{array}$ & & + & & & & & + & & & & \\
\hline \multirow{2}{*}{5} & $\begin{array}{l}\text { Take } \\
\text { place }\end{array}$ & $\begin{array}{l}\text { Yes } \\
\text { No }\end{array}$ & $\checkmark$ & X & $\checkmark$ & & & & & & & $\checkmark$ \\
\hline & $\begin{array}{l}\text { Planned } \\
\text { Situation }\end{array}$ & & + & + & + & & & & & & & + \\
\hline \multirow[t]{2}{*}{7} & $\begin{array}{l}\text { Take } \\
\text { place }\end{array}$ & $\begin{array}{l}\text { Yes } \\
\text { No }\end{array}$ & $\checkmark$ & $\checkmark$ & $\checkmark$ & & $\checkmark$ & & & & & $\checkmark$ \\
\hline & $\begin{array}{l}\text { Planned } \\
\text { Situation }\end{array}$ & & + & + & + & & + & & & & & + \\
\hline \multirow{2}{*}{8} & $\begin{array}{l}\text { Take } \\
\text { place }\end{array}$ & $\begin{array}{l}\text { Yes } \\
\text { No }\end{array}$ & $\checkmark$ & $\checkmark$ & & & & & & $\checkmark$ & & \\
\hline & $\begin{array}{l}\text { Planned } \\
\text { Situation }\end{array}$ & & + & + & & & & & & + & & \\
\hline \multirow{2}{*}{9} & $\begin{array}{l}\text { Take } \\
\text { place }\end{array}$ & $\begin{array}{l}\text { Yes } \\
\text { No }\end{array}$ & $\checkmark$ & & & & & & $\checkmark$ & & & \\
\hline & $\begin{array}{l}\text { Planned } \\
\text { Situation }\end{array}$ & & + & & & & & & + & & & \\
\hline
\end{tabular}

In the first activity, one of the students was asked to observe by holding two bottles filled with cold water ant the other with hot water. With these observations based on tactile experience, students were able to observe temperature changes between the two materials. Simultaneously, the transfer of energy from the hand of the student to the ice and from hot water to student's hand occurs. The reason of being one of hand warm with time and the other hand cold simultaneously was questioned by putting analytical thinking

Int. J. Eval. \& Res. Educ. Vol. 8, No. 1, March 2019: 90 - 96 
forward. According to observation in order to teach the concept of heat transfer in the first activity, integrating a phenomenon that occurs frequently in daily life has improved the positive attitude of students. Students want to be taught other lessons in this way, too. Table 3 shows the analysis of activities in terms of the science process skills

In the design phase, the planned skill for each activity is shown as $(+)$. The taking place of skills for each activity at the time of implementation is shown as yes $(\square)$ or no (x). According to these results, most of the planned skills that were designed were took place. The only skills that do not take place are the ability to measurement classification related the 5th and using data and modeling related 9 th activities.

\section{CONCLUSION}

The mission of science education is to enable all students to use science process skill include observing qualities, measuring quantities, classifying, inferring, predicting, experimenting, and communicating to be able to define the real-world phenomena and problems around them . Meanwhile, the one crucial point that needs to be emphasized is that science process is not just convenient in science, but in any situation that requires critical thinking. So, laboratory works or in other words practical works in science education are quite important in terms of learning and skill development in science education. Therefore, practical work in science teaching that is acknowledged that promotes the engagement and interest and curiosity of students as well as developing a range of skills, science knowledge, and conceptual understanding. But it is a common accepted that science education particularly depends on intensive use of vision sense in order to receive the knowledge of the outside world or to be capable in recording information obtained by observation. Scientific knowledge is based on observational knowledge. It is accepted that observational evidence is crucial for the scientific discovery and the application of scientific theories to practical problems. Contrary to broad misunderstanding, observations are made with our own eyes, observation in science can be made by seeing, hearing, feeling, and smelling, too. However some of the blind individuals for example use non-vision senses such as hearing and touch for learning and functional tasks. Of course nobody thinks they should be deprived of the vast world of science because of having vision loss. The truth is that they typically need variety of opportunities to explore and examine real materials or models by touch or putting across through visual observation. Evidence shows that there is a serious educational gap both in bringing hands-on investigative activities into the classroom and in performing of science-enquiry principles especially at segregate schools. The findings of this study pointed out that there were great shortcomings in the whole process of teaching science instructions and in carrying out scientific practical works. As predicted there was poor reception of the science process skills.

In this study we have designed and developed activity and activity materials to meet students' needs related learning in science and to teach science process skills. Besides that these activities were aimed to develop scientific way of thinking by providing "multiple opportunities to work with these skills in different content areas and contexts". In addition to scientific process skills, the development of necessary social skills like as share, collaborate effectively, share, defend and extend ideas in groups was observed in this study. For example after implementation of the activities, we have witnessed one of the student these words: "This time I discussed scientific things with my friend whom I discussed for absurd things before. This was an interesting experience". As a result, the activities we have prepared for the development of the students' scientific process skills have been successfully implemented. Most of the skills planned for each activity have taken place. Unrealized skills can be explained by the fact that the students have had little activity before. It was observed that in the interviews made with the students after implementation of study, the students wanted the science lessons to be conducted in this way. But one the important points to consider is that designing instructional materials and activities for science requires a close collaboration of teachers, parents, students, and experts working on activity materials. Materials that are more appropriate to the students' unique needs can be developed by working in collaboration. The activities designed and developed according to the students' unique needs can be developed in social skills as well as the scientific process skills of the students. As visually impaired students easily get distracted by unnecessary details, to minimize distractions and allow them to focus on the main idea of the subject, activities and materials should be prepared as simple and as possible. This fact is especially essential in terms of time required for students to be able to socialize.

\section{REFERENCES}

[1] Holahan, G. G., McFarland, J. and Piccillo, B. A., "Elementary school science for students with disabilities. Remedial and Special Education," vol. 15(2), pp. 86-93, 1994.

[2] National Research Council (NRC), "National science education standards," National Academy Press, Washington DC, 1996. 
[3] Hadary, D. and Cohen, S., "Science activities for blind, deaf, and emotionally disturbed students," University Park Press, College Park, MD, 1978.

[4] Konza, D., "Inclusion of Students with Disabilities in New Times: Responding to the Challenge," In P. Kell, W. Vialle, D. Konza, and G. Vogl, et al, "Learning and the Learner: Exploring Learning for New Times," University of Woolongong, Wollongong, 2008.

[5] "No Child Left Behind Act of 2001," Pub. L, pp. 107-110, 115 Stat.1425, 2002.

[6] Chiapetta, E., "A review of Piagetian studies relevant to science instruction at the secondary and college level," Science Education, vol. 60, pp. 253-261, 1976.

[7] Griffin, P., McGaw, B. and Care, E., "Assessment and teaching of 21st century skills," Springer, Dordrecht, 2012.

[8] Kizilaslan, A. and Kizilaslan, M., "Anxiety in visually impaired students about the future," The International Journal of Evaluation and Research in Education, vol. 7(2), pp. 152-158, 2018.

[9] Thomas, H. and Imrie, R., "The interrelationships between environment and disability". Local Environment, vol. 13, pp. 477-483, 2008.

[10] Kumar, D., Ramasamy, R. and Stefanich, G., "Science for students with visual impairments: Teaching suggestions and policy implications for secondary educators," Electronic Journal of Science Education, vol. 5(3), Retrieved, from http://ejse.southwestern.edu/article/view/7658/542, March, 2016.

[11] Andrews, S., "Using inclusive literature to promote positive attitudes toward disabilities," Journal of Adolescent and Adult Literacy, vol. 41, pp. 420-426, 1998.

[12] Thomas, H. and Imrie, R. "The interrelationships between environment and disability," Local Environment, vol. 13, pp. 477-483, 2008.

[13] Gast, D.L., Winterling, V., Wolery, M. and Farmer, J.A., "Teaching first-aid skills to students with moderate handicaps in small group instruction,". Education \& Treatment of Children, vol. 15, pp. 101-124, 1992.

[14] Maguvhe, M.O., "Being a blind researcher in South Africa: A critical assessment," Perspectives in Education, vol. 21(3), pp. 117-119, 2003.

[15] Mastropieri, M.A. and Scruggs, T.E., "The construction of scientific knowledge by students with mild disabilities," The Journal of Special Education, vol. 28(3), pp. 307-321, 1994.

[16] Kızılaslan, A. and Sözbilir, M., "Maddenin halleri ve 1S1 öğretim tasarım modelinin değerlendirilmesi ögrenci ve öğretmen görüşleri," Marmara Üniversitesi Eğitim Bilimleri Dergisi, vol. 48(48), pp. 111-127, 2018.

[17] Harfield, T., Davies, K., Hede, J., Panko, M. and Kenley, R., "Activity-based teaching for Unitec New Zealand construction students," Emirates Journal for Engineering Research, vol. 12(1), pp. 57-63, 2007.

[18] Anderson, T. and Shattuck, J., "Design-Based Research: A Decade of Progress in Education Research?," Educational Researcher, vol. 41(1), pp. 16-25, 2012.

[19] Yin, R.K., "Case study research: design and methods (5th ed.)," SAGE Publication, California, 2014.

[20] Barrows, H.S., "Problem-Based Learning Applied to Medical Education," Southern Illinois University School of Medicine, Springfield, IL, 2000.

[21] Batd1, V., "The effect of activity-based learning approach on academic achievement: A meta-analytic and thematic," study. E-International Journal of Educational Research, vol. 5(3), pp. 39-55, 2014.

[22] Harfield, T., Davies, K., Hede, J., Panko, M. and Kenley, R., "Activity-based teaching for Unitec New Zealand construction students," Emirates Journal for Engineering Research, vol. 12(1), pp. 57-63, 2007.

[23] Çakmak, S., Karakoç, T., Şafak, P., and Kan, A., "Identifying the reading speed of low vision student's at elementary level," International Journal in IT \& Engineering, vol. 2(10), pp. 38-48, 2014.

Int. J. Eval. \& Res. Educ. Vol. 8, No. 1, March 2019: 90 - 96 